\title{
Revision of judicial acts in Russia in connection with the appeal of new circumstances on considered criminal cases
}

\begin{abstract}
The article analyzes the current procedure for the use of one of the most well-known in the Russian judicial practice procedural ways of correcting admitted judicial errors in criminal cases already considered by the courts. In this capacity, the resumption of proceedings in a criminal case is postponed due to new or newly discovered circumstances, the procedural possibilities of which are very high. Considering this institution, the author draws attention to the fact that the revision of the final judgment in cassation and supervision in Russia now takes place only in cases where violations of the law are revealed that have affected or could affect the thoroughness and completeness of the investigation of the circumstances of the case, the correctness of the criminal-legal assessment of the deed, as well as to ensure the rights of participants in criminal proceedings. In such cases, the cancellation of the final judgment and the return of the criminal case for a new trial before the first or appellate court allow the criminal investigative bodies and the court to remove their own violations. And, regardless of whether they were intentional, or were the result of a conscientious error. The fact that these violations could and should have been prevented or corrected before the relevant decision on the criminal case came into force does not eliminate the need for their subsequent correction. Describing the procedural procedures for the resumption of proceedings in a criminal case due to new or newly discovered circumstances, the author draws attention to the fact that their specifics are predetermined by the nature of judicial errors, for which, in fact, this production is intended. He also notes that there is nothing exceptional, extraordinary in it, since it is not applied either in place of or after other possibilities for reviewing the judicial act have been exhausted, but quite independently, i.e. if circumstances are discovered that either arose after the criminal case was examined by a court, or already existed at the time of its consideration, but were not known to the court. However, at the same time, not any of them should be taken into account, but only those that do not allow ultimately to evaluate the decisions made in the criminal case as legitimate, justified and fair.
\end{abstract}

Keywords: newly revealed circumstances, renewal of production on criminal case, prosecutor's conclusion, correction of judicial errors, new circumstances, revision of the judicial acts, human right potential
Volume 3 Issue 5 - 2019

\author{
Alexander S Shatalov \\ Department of Criminal Law and Criminal Science, National \\ Research University Higher School of Economics, Russia

\begin{abstract}
Correspondence: Alexander S Shatalov, Department of Criminal Law and Criminal Science, National Research University Higher School of Economics, Doctor of Juridical Sciences, 20 Myasnitskaya Str, Moscow 101000 , Russia, Tel +7 (926) 71088 66, +7 (909) 62788 66,

Email asshatalov@rambler.ru, asshatalov@hse.ru
\end{abstract}

Received: August 02, 2018 | Published: October 02, 2019

\section{Methodology manuscripts}

The goal set by the author in writing this article was to fulfill the scientific task due to the need to obtain, on the basis of studies made, the most significant and controversial issues of new scientifically grounded theoretical and practical provisions on the resumption of criminal proceedings in view of new and newly discovered circumstances in Russian criminal proceedings, as well as in the development of proposals for changing certain provisions of the Code of Criminal Procedure of the Russian Federation and tics of their application. The methodology of the study was based on a dialectical approach to the cognition of phenomena and processes of objective reality, which made it possible to conduct a scientific analysis of the revision of court decisions after the entry of judgments and other court decisions as an important activity and the most complex segment in criminal proceedings. ${ }^{1}$ The following general scientific and special methods were used: a statistical method, including the collection and analysis of statistical data on the revision of procedural decisions; historical-legal and logical-legal methods, which allowed to analyze the mechanism of activity of participants in the judicial proceedings; specifically, sociological method, which was widely used in the questioning and interviewing of investigators, advocates, prosecutors and judges. Methods of system research and modelling made it possible to study the category of "review of court decisions" on the basis of various theoretical concepts and formulate some noteworthy proposals. Comparative legal method allowed formulating recommendations on clarifying the content of certain norms of the Criminal Procedure Code of the Russian Federation. ${ }^{2}$

The application of these methods was based on their combination with logical methods (induction, deduction, analysis, synthesis, hypothesis, analogy) and methods of argument widely used in scientific research. The use of these methods served the ultimate goal-to learn the advantages and disadvantages of the current procedural regulation of the review of enforceable judgments in view of the emergence of new or newly discovered circumstances, a comprehensive examination of the problems arising, systematization of the knowledge gained, and justification of the conclusions and recommendations formulated in this article. Renewal of production on criminal case in connection with newly-revealed circumstances is the oldest institute of the Russian law of criminal procedure. Having received standard fixing in the Charter of criminal legal proceedings 
of 1864, it not only kept, but also greatly increased the positions in all codified sources of the Soviet criminal procedure legislation (CPC of RSFSR - Criminal Procedure Code of Russian Soviet Federative Socialist Republic of 1922, 1923 and 1960). Nevertheless, its human rights potential was used extremely seldom in jurisprudence. In many respects it was caused by that in the sphere of revision of the judicial acts, which have come into effect, supervising production less difficult in the procedural relation dominated, and the solution of a question on their revision on newly-revealed circumstances entirely depended on a discretion of the prosecutor which refusal about it wasn't subject to judicial control. ${ }^{3,4}$

Adoption of the Constitution of the RF which has proclaimed the supreme value of human rights and freedoms, and determined their protection as a duty of the state (1993); recognition by Russia of jurisdiction of the European Court on human rights in questions of application and interpretation of the Convention on protection of human rights and fundamental freedoms (1998); generated need of improvement of judicial acts revision mechanism created in the Soviet period. As a result of criminal legal proceedings reforming, the updated procedures of their revision in view of the new or newlyrevealed circumstances were presented in the current Criminal Procedure Code of the RF, which come into force since July 1, $2002 .{ }^{5}$ It didn't lead to cardinal changes of the Soviet model of this institute, but nevertheless a certain positive effect was reached. First of all, due to inclusion of resolutions of the Constitutional Court of the RF and decisions of the European Court on human rights in number of the bases leading to renewal of criminal proceedings, and also due to establishment of judicial control of the prosecutor's decisions taken by the reason of the results of message checking, testifying to need of duly revision of the judicial act. As a result, human rights potential of this institute has greatly increased. ${ }^{6}$

Before passing to its detailed consideration, we will pay attention to, that revision of the judgment which has come to effect in a cassation and supervising order, now takes place when the following circumstances come to light: violations of the law, which affected or could affect comprehensiveness and completeness of investigation of facts of a case, correctness of a criminal and legal assessment of deeds, and also ensuring the rights of participants of criminal proceedings.

In such cases abolition of the final court decision and restitution of the criminal case to the court for the new trial by the first or appeal instance allow the organs of criminal prosecution and the court to eliminate disturbances. Regardless of the fact whether they were deliberate or the result of the innocent mistake. The circumstance that these disturbances could and had to be prevented or corrected before carrying criminal case decision into effect does not eliminate the necessity of their following correction. ${ }^{7,8}$

In contrast to the review of judgment in the court of appeal resumption of case takes place in view of such circumstances which occurred after legal investigation or existed while the investigation but were not known to the court. At the same time only circumstances which do not allow to evaluate criminal judgments as legal, valid and just are taken into consideration. ${ }^{9}$

Resuming criminal procedure in view of the new circumstances the court provides not only the making up for a deficiency in prosecutive jurisdiction and legal proceedings but the opportunity to investigate the facts which were admitted by the criminal law as important for determination of reasons and scopes of penal protection, but which couldn't be the subject of investigation on the criminal case earlier. This mechanism may and must be used for the elimination of violations made while the criminal procedure, but not when the opportunities of their correction by appeal and by supervision came to the end. In that sense regarding these procedures it must not be taken as reserve one. ${ }^{10-13}$

Provided by the law reasons of reconsideration of the verdict, resolution, court decision considering new or new discovered circumstances (art. 413 PCC RF) predetermine legal procedure of its practical realization. In contrast to the appeal proceedings, consisting in the re-examination of the same criminal case by the court, legal proceedings considering the new or new discovered facts include in particular the implementation of legal proceedings and making decisions typical not only for the trial but also for pre-trial proceedings. $^{14}$

In confirmation of the stated information one can mention, for example, the institution of the given procedure by the public prosecutor, an investigation of new and newly revealed circumstances, assuming implementation of investigative actions (examination, interrogation, forensic inquiry, seizure and etc.) and also the following reference of materials to the court to try criminal cases taking into account established factual data as a result of the conducted investigation (art. art. 415-418 code of criminal procedure of the Russian Federation).

So the legal-protective potential of the present institute affects cases when separated circumstances have already become obvious after entry into force sentence, determination and judgment of a court according to an examined case. Relevance in law of these circumstances is so high that enables an interested party to throw doubt on legality relevance and justice of coming into force court decision. In such cases sentence, determination and judgment of the court can be abolished but the procedure of the criminal case can be reopened in new and newly revealed circumstances in the regulated order chapter 49 code of criminal procedure of the Russian Federation (art. art. 413-419). In its scopes any coming into force decisions can be reconsidered. Review of a sentence according to newly revealed circumstances in favour of any term convicted person is not limited. Even his death is not the obstacle to reopen the criminal case procedure in intentions of rehabilitation.

There are two groups of circumstances according to resumption of the criminal case procedure. Newly revealed circumstances form the first group, that is, the circumstances which existed during entry into force sentence and any court decision but the court did not adjudge them. New circumstances form the second group, that is, the circumstances which are not adjudged by the court during passing of court decision eliminating criminality and punishability of an act.

Newly revealed circumstances are regarded as:

a. Regulated entered into force by the court sentence notorious falsity of victim or witness evidence, inference of an expert, and equally falsity of tangible evidence, records of investigative and legal actions and other documents or notorious irregularity of transference, entailed judgment of illegal, unsound and unjust sentence, imposition of illegal or unsound determination or decision (item 1 part 3 Article 413 code of criminal procedure of the Russian Federation);

iSee: p. 2 Resolution of the Constitutional Court of the Russian Federation on the case about the verification of constitutionality art.art.237, 413 and 418 of the PCC of the Russian Federation in connection with the inquiry of the Presidium of the Kurgan regional court, dated 16 may 2007. № 6-P. 
b. Regulated entered into force by a court sentence criminal acts of an investigator, an interrogator or a prosecutor, entailed imposition of illegal or unsound determination or decision (item 2 part 3 Article 413 code of criminal procedure of the Russian Federation);

c. Established by a lawful sentence of a court a judge's criminal acts committed by him dealing with the case (item 3 part 3 Article 431 RCC)

Mentioned circumstances may be established as by a sentence of a court and as well as by a decision of a court, by a decision of an investigator about the stoppage of a case after expiration of the period, because of the act of amnesty or pardon, because of the accused death, because the accused is under the age of criminal responsibility. Using such law interpretation there is one criterion of the final court decision. It is necessary to mention the importance of new reopened circumstances revealed during the investigation and connection with legal court decision. We can come to the conclusion that in spite of mentioned legal decisions new reopened circumstances may be established by a decision of the stoppage of legal proceeding (when there are no reasons for its stoppage). Notorious false sources of evidence information are the result of their improper origin. As a rule, these false sources are: perjury, deliberate false investigator's conclusions, deliberate distortion of the exact contents of documents, the falsification of exhibits, illiterate translation. These facts may be the ground of the legal proceeding renewal when they were established by a legal decision and criminals are convicted before the renewal of the case because of new or reopened circumstances. ${ }^{\text {ii }}$

Under the deliberate criminal acts of officials mentioned in the second subgroup of new reopened circumstances we mention their illegal activity or criminal inactivity lead to the distortion of real circumstances of a case. They can be expressed in the evidence falsification, in an unreasonable acquitted court decision, in stoppage of a case. Often these acts are self-interested. However criminal abuses of the officials investigating a case are the ground for renewal of legal proceeding if there is a reasonable connection between unlawful acts and illegal court decision. Criminal abuse of some judges leads to elimination of a court decision irrespective of whether or not this decision has been unlawful or ungrounded. Law requires that every such fact should constitute a ground for cancelling the court decision made on the criminal case in question.

Thus, it is argued that the range of newly discovered circumstances must be strictly reduced to those fully listed in the Criminal Procedural Code of the Russian Federation. This approach of the Russian legislator cannot be completely justified as it actually excludes from the sphere of court control a certain segment of court acts considered unlawful on the grounds that they incorrectly reflect some crucial circumstances of a given criminal case. This is just as typical of the new circumstances whose range in the Criminal Procedural Code is limited exclusively to those eliminating the criminal character and punishability of a certain act. This means that only when these circumstances are present does the given act, though seemingly falling under the Special part of the RF Criminal Code but actually aimed at protecting legal interests; lose the characteristics of a crime. The circumstances traditionally referred to this group include necessary defense; infliction of harm while arresting a person suspected of committing a crime; extreme necessity; physical or psychological compulsion; justifiable risk; carrying out an order or an instruction (Articles 37-42 of the RF Criminal Code).

iiSee: Bulletin of the Supreme Court of RSFSR. 1981.№5, p. 4; Bulletin of the Supreme Court.1998. №3, p. 9.
Just as newly discovered circumstances, new ones are subdivided into four groups. They comprise the following:

a. The RF Constitutional Court recognizes the law applied by the court in judging a certain criminal case as not being in keeping with the RF Constitution; (item 1, part 4, Article 413 of the PF Criminal Procedural Code);

b. The European Court on Human Rights states the violation of the provisions of the Convention on Human Rights and Basic Freedoms by a RF court considering a criminal case that is connected with: an application of a federal law which does not correspond to the provisions of the above mentioned Convention; other breaches of the above Convention (item 2, part 4, Article 413 of the RF Criminal Procedural Code);

c. The offense during the period when the criminal case is being considered by the court or after the judgment has been rendered new socially dangerous consequences of the offense charged to the accused, which are grounds for charging him with a more serious crime;

d. Other new circumstances (item 3, part 4, Article 413 of the RF Criminal Procedural Code), i.e. Those which by themselves or together with the earlier discovered circumstances point to the illegality or groundlessness of the decision previously made by the court.

It should be noted that the illegality of the court decisions on a certain case cannot form the ground for the renewal of the criminal procedure in relation to the case on the basis of the new or newly discovered circumstances, if this illegality has been a result of a court error, which has, among other things, been confirmed -the court decision having come into force - by the supplementary evidence proving the convicted not or less guilty.

Thus one of the new circumstances, registered in the Criminal Procedure Code of RF, presupposes that the Constitutional Court of RF decides that the law, applied by the court in this very criminal case, does not correspond to the Constitution of the RF. Taking constitutional control this adjudicatory body has a right to regard any enactment as completely or partially contravening the Constitution. Its decrees are often ultimate, without appeal. They don not demand any additional affordance of their justifiability and come into force immediately after their proclamation. Judgments of the Constitutional Court of RF are obligatory for all representative, executive and adjudicatory bodies of the government, of institutions of local governing, for all officials, citizens and their unions. Deeds or their separate regulations, declared as unconstitutional, lose validity, and the court sentences, decisions and decrees, based on these deeds, are to be reconsidered by the Presidium of the Supreme Court of RF by the production of the President of the Supreme Court of RF. Such a retrial should take place by the first month since the day of receipt of the given production at the latest. According to the results of this retrial the Presidium of the Supreme Court of RF reverses or makes alternations in the judgments of the criminal case in accordance with the determination of the Constitutional Court of RF. Within 3 days the copies of the judgment of the Presidium of the Supreme Court of RF are sent to the Constitutional Court, also to a person concerned by this determination and to the Prosecutor.

The following new circumstance of the Criminal Procedure Code of RF consists in the fact that the European Court of Human Rights has found some violations of the regulations of the Convention for 
the Protection of Human Rights and Fundamental Freedoms in the criminal case considered by the Court of RF. This is connected not only to the application of the federal law but also to some other violations of the Convention regulations. Recognition of this condition is caused by the fact that universally recognized principals and norms of international law as well as international agreements are the main body of the legislation of RF that settles criminal procedures (part 3 , Article 1 of the RF Criminal Procedure Code). According to this, Russian courts while administrating justice must proceed from the fact that universally recognized principals and norms of the international law, registered in international covenants, conventions, declarations, communiqués, protocols and in other similar documents can be resorted to immediately in the cases when the norms of the national legislation contravene the regulations of the international agreement.

These are international agreements that play the dominant role in the sphere of the protection of the human rights and fundamental freedoms including the matter of correction of judicial errors. For example, the International Covenant on Civil and Political Rights that stipulates a possibility of a retrial of ultimate judgments providing that some new or newly discovered condition prove a judicial error without controversy (item 6 Article 14). Thus this covenant has better opportunities for correction of judicial errors than the Russian Criminal-Procedure legislation. That is exactly the reason why judicial work connected to court realization of the general jurisdiction of universally recognized principals and norms of the international law and international agreements at the internal level always merits a principal concern. ${ }^{\text {iii }}$

In light of the Russian ratification of the European Convention for the Protection of Human Rights and Fundamental Freedoms, that took place in March, 30, 1998, Russian people got a right to appeal to the European Court (Strasbourg). The court's terms of reference cover consideration of appeals concerning violation of basic human rights (such as right to life, right to a fair trial, right to keep legal personality in any country, freedom from torture and inhuman or degrading treatment etc.). Having joined to the Council of Europe Russian took over the responsibility to preserve and to observe rights and freedoms stipulated in the European convention and to admit jurisdiction of the European Court. As a result, all the citizens of RF have a right to appeal to this court if they find their rights violated. But still the issue of their appeal may be only the rights guaranteed by the Constitution of RF. The European Court itself is not the supreme body regarding to the state judicial system which is a member of the Convention. That is why it cannot reverse a judgment passed by a public authority or by the national court; it also has no right to give instructions to the legislator, to control the national legislation or the court practice. Moreover, the European court has no right to give instructions concerning taking measures that may have some legal effects. This court considers appeals only to find out whether the demands of the Convention have been violated or not.

The rules of the European Court do not state any normative terms of the consideration of the received appeals. Furthermore, an appeal of a Russian citizen in particular may be taken to consideration provided that the following conditions are met:

a. If the rights of a person were violated after the May 5th, 1998 (i.e. after the Convention had come into force for RF);

iiiSee e.g. Resolution of the Plenum of the Supreme Court of RF "on the application by the courts of general jurisdiction of the universally recognized principles and norms of international law and the international treaties of RF", dated 10 October 2003, № 5. b. If an application is based on sufficient proofs of violation, specified by the norms of the Convention or by the judgments (precedents) of the European Court;

c. If all the internal potentialities for the restitution are exhausted.

Taking affirmative decisions concerning received appeals the European Court states which of the rights have been violated by the state-defendant and are to be eliminated and it also states which norms of the law contravening the Convention of the Human Rights should be changed by the state. It is European Commission of Human Rights that is responsible for observance of the obligations, taken by the state members of the Europe Council.

In case the European court detects a breach of the regulations of the Convention for the Protection of Human Rights and Fundamental Freedoms on the part of RF, retrials, revision of court decisions or writs are carried out by the Presidium of the Supreme Court upon recommendations of the Chief Justice of the Supreme Court of RF. It should be done not later than in a month since the moment of the receipt of the given recommendations. Following to the results of this revision the Presidium of the Supreme Court reverses or alters the court decisions of this criminal case in accordance with determinations of the European Court of Human rights. The copies of the determination are sent to the interested person, to the Prosecutor and to the Representative of the RF at the European Court of Human rights within 3 days. In the third subgroup of new circumstances that appeared in the Criminal Procedure Code of the Russian Federation in 2013, there is an offensive in the period when the criminal case is considered by a court or after a court decision has been made on the new socially dangerous consequences of the offense charged to the accused. However, this is not a matter of any consequences, but only of those that are grounds for charging him with a more serious crime.

As for the third group of the new circumstances, regarded in the Criminal Procedure Code of RF as to "others", they are made up by unknown or newly revealed information which testifies to the invalidity of the court decision. Unawareness of these facts has entailed fair error of the court concerning original conditions of the given crime. The list of such circumstances is not registered in the law. But still it contains the main demand which these circumstances should meet to be considered as legal foundation for the reopening of the case: they should eliminate guilt and punishability of the action. Thus it is commonly accepted among Russian courts to refer the following circumstances to the unknown or newly revealed:

a. False confession of the condemned;

b. Establishment of the facts that testify that the crime has been committed by some other person;

c. Getting new information within the inquiry of some other criminal cases so that this information affects the nature of indictment;

d. Establishment of the fact that the person considered to be killed is actually alive;

e. Establishment of diminished responsibility of the condemned at the moment of the commitment of the socially dangerous act;

f. Occurrence of the new advisory action which essentially differs from the one stated in the case information;

Alternation of the original evidence after the verdict has come into force (under condition that this evidence provided a basis for the conviction) 
By a common rule every new circumstance should be stated by the court verdict which has come into force. At the same time, they not always can be established in the verdict. It is typical for the cases of defendant's death, expiration of period of limitation, proclamation of an act of grace or act of oblivion, age of irresponsibility and of some others. In such situations newly revealed circumstances can be stated not only by a verdict but also by a court decision, a writ or by an investigator's decision about abatement of action for the listed reasons. If doubts about lawfulness and validity of the court decision are based on the circumstances which earlier have been obscure to the participants of a legal procedure and have become apparent after decision's coming into force, the matter of revision of such a decision can be stated only in the course of proceedings of newly revealed circumstances.

Thus, by defining the range of new and newly revealed circumstances as a basis for revision of law-pleas, the Criminal Procedural Code of the RF practically sets an exhaustive list of such circumstances. The day of disclosure of new and newly revealed circumstances is:The day of coming into effect of a verdict, a court decision or a writ concerning a person guilty of false evidence, false proofs, incorrect interpretation or criminal actions, committed in the course of court proceedings - in the cases stipulated in item 3 Article 413 of the Criminal Procedural Code; The day of coming into effect of a decision of the Constitutional Court of the Russian Federation of irrelevance between the laws, applied in the given criminal case and the Constitution - in the case stipulated in item 1 part 4 Article 413 of the Criminal Procedural Code; The day of coming into force of the decision of the European Court of Human rights about violation of regulations of Convention for the Protection of Human Rights and Fundamental Freedoms - in the case stated in p. 2 p. 4 art. 413 of the Criminal Procedural Code; The day of Prosecutor's subscription of the necessity of reopening the court proceedings in view of new circumstances - in the case stipulated in p. 3 p. 4 art. 413 of the Criminal Procedural Code.

Revision of justificatory verdict or court decision, determination of abatement of action, or of conviction in view of leniency of a punishment or necessity of application of a much stricter punishment can be made within a year since the day of disclosure of new and newly revealed circumstances and only within the period of limitation of criminal prosecution, stipulated in Article 78 of the Criminal Procedural Code. These periods are reckoned since the day of commitment of the crime and till the moment when the verdict comes into force. Running of the time period can be stopped if the person which has committed the crime deviates from investigation or trial. In particular, a justificatory verdict, determination of abatement of action or a conviction cannot be reviewed for reasons connected to deteriorate of the convict's state on the expiry of the following periods of time:

a. Two years since the day of commitment of minor offence (i.e. a crime, punished by less than 2 years of deprivation of liberty);

b. Six years since the day of commitment of a crime of average gravity (i.e. a crime, punished by less than 5 years of deprivation of liberty);

c. Ten years since the day of commitment of a grave crime (i.e. a crime, punished by less than 10 years of deprivation of liberty);

d. Fifteen years since the day of commitment of a high crime (i.e. a crime, punished by more than 10 years of deprivation of liberty).
The right to initiate proceedings in view of new or newly revealed circumstances belongs to Prosecutor. Citizen's reports, official's reports and the data received in the process of preliminary investigation and judicial inquiry of other criminal cases. Accordingly, if a report contains a reference to availability of newly revealed circumstances (item 3 part 3 Article 413 of the Criminal Procedural Code), Prosecutor discerns to initiate corresponding proceedings, examines these circumstances, reclaims a copy of the verdict and notice of entry. If a report contains a reference to availability of other unknown or newly revealed data, which testify to invalidity of the court's decision and thus eliminate criminality and punishability of the action (item 3 part 4 article 413 of the Criminal Procedural Code), Prosecutor discerns to initiate proceedings in view of new circumstances and sends corresponding materials to the head of investigative agency for examination of these circumstances and solution of the problem of criminal prosecution in response to the revealed violation of legislation in force. Examination of new circumstances can be accompanied by investigatory or other legal proceedings in accordance with procedure stated in the Criminal Procedural Code. If necessary, an inquiry agency is given a commission to resort to special investigation means. ${ }^{14-17}$

The investigation period is not determined. It is considered to correspond with the general term of preliminary investigations stipulated in the Criminal Code ( 2 months). With the examination and investigation completed and with the presence of the ground for renewal of production on criminal case Prosecutor sends the criminal case with his/her conclusion and also with the copy of the verdict and materials of examination or investigation to court. If such a ground is missing, the Prosecutor discontinues the initiated proceedings. Court ruling is brought to the notice of interested persons. Herein it is explained to them that they have a right to appeal this decision at court, which is entitled by the Criminal Code to solve a problem of renewal of production on criminal case in view of new or newly revealed circumstances. ${ }^{\text {iv }}$

In fact, the Prosecutor's conclusion is a specific type of his/her petition (act of response) which poses the problem of necessity to renew the production on the criminal case in view of new or newly revealed circumstances to the respective court. According to the court which has rendered decision which first came into force and then got appealed, the prosecutor's conclusion should be examined by the following courts:

i. By district courts - concerning verdict and court ruling of justice of the peace;

ii. By the presidium of the supreme court of the republic, the presidium of the regional and territory court, of federal court, of court of autonomous region and autonomous district concerning verdict, decision or ruling of a district court;

Judicial division for criminal cases of the Supreme Court - concerning verdict, decision, ruling of the Supreme Court of the republic, territory or region court, municipal court of federal significance, court of autonomous region and autonomous district. by the same courts, if judicial decisions were not subjects of the review of the Supreme Court of the Russian Federation - concerning verdict, judicial decision of the Trial of the Judicial Division for Criminal Cases of the Supreme Court or the Military Collegium of the Supreme Court, rendered by them in the course of criminal proceedings as a court of appeal or cassation.

${ }^{\text {iv }}$ See: p. 18 Resolution of the Plenum of the Supreme Court of RF "On the practice of court examination of complaints under Article 125 of the Criminal Procedure Code of RF” dated 10 February 2009 № 1 . 
i. By district (naval) military courts - concerning a verdict, judicial decision or ruling of the garrison military court.

ii. By the military collegium of the supreme court of the russian federation - concerning a verdict, judicial decision or ruling of the district (naval) military court.

iii. By the presidium of the supreme court of the russian federation - concerning a ruling of the presidium of the supreme court of the russian federation.

Thus judicial decisions, which have already come into force, can be reviewed in the view of new or newly revealed circumstances at reconsideration of the case in court. Moreover, previous consideration of the criminal case at appeal or cassation hearing does not preclude from its consideration of the same court in the form of renewal of production on criminal case in the view of new or newly revealed circumstances. Court of superior jurisdiction has a right to involve in the proceedings materials of the verification and investigation, according to which renewal of production on criminal case in the view of new or newly revealed circumstances is within the competence of the inferior court. However, it is not authorized to make alternations in the early made decisions. Therefore, the court, which considers the prosecutor's conclusion concerning the necessity of renewal of production on criminal case in the view of new or newly revealed circumstances, should rely upon the grounds for changing earlier made decision and reverse this decision and then send this criminal case to court for a new court examination.

Prosecutor's conclusion concerning renewal of production on criminal case in the view of new or newly revealed circumstances is going to be considered in a court examination within one month and in a hearing of the Supreme Court within 2 months observing the following rules:

1. The Secretary of judicial session keeps the minutes, the content of which may be later alternated by the parties;

2. Judicial session necessarily involves the prosecutor and if a special petition is submitted - convicted or acquitted, their defenders and legal representatives, the person against whom the case was dismissed in court (if the prosecutors conclusion contains the issue of the abolition of such decisions);

3. Circumstances of the case, the contents of the earlier decisions, the prosecutor's arguments are reported to one of the judges;

4. After the speech of the judge-rapporteur and his answers to the questions aroused, the prosecutor leads justification of his/her conclusion concerning the necessity of renewal of production on criminal case in the view of new or newly revealed circumstances.

5. Other interested parties involved in the hearing have the right to give oral explanations after the prosecutor's speech.

6. After hearing the parties the court retires to the jury room for making the final decision, as the presiding officer announces to the audience in the courtroom.

7. Having considered the conclusion of the prosecutor, the court shall make one of the following decisions:

a. annulment of the sentence, writ of decision of the court and the transfer of criminal case for the new court proceedings;

b. annulment of the sentence, writ of decision of the court and termination of the criminal case (in this case, the court at the same time decides either to transfer the criminal case for a new trial, or to terminate the proceedings in whole or in part)

c. rejection of the prosecutor's conclusion.

The decision on the prosecutor's conclusion is made in the jury room by the majority of the judges. The presiding officer votes at last. At an equal number of votes the prosecutor's conclusion gets rejected.

A rule of court is signed by the presiding officer while a court decree is signed by all the judges involved in the hearings. Regardless of the form every such a decision should contain a brief description of the crime, for committing of which the person is convicted and the prosecutor's arguments for the necessity of the renewal of production on criminal case in the view of new or newly revealed circumstances. While rejecting the decisions which have been made earlier the court should refer to the circumstances which brought about rendition of illegal, unreasonable or unjust court decision or to the grounds of the rejection of the earlier made court decision. ${ }^{18}$

The court which should consider the respective prosecutor's conclusion makes a decision concerning rejection of the sentence and transfer of the criminal case for the new court proceedings to the court under occurrence of the new factual circumstances which may serve as a ground for aggravation of the state of the person condemned or acquitted. ${ }^{v}$ This court cannot make any decisions which lead to the aggravation of the state of the accused by order of Article 413 of the Criminal Procedure Code of RF and also in accordance with the fact that such a procedural mechanism ensuring making such decisions is not present in the current legislation. Within seven days from the date of the pronouncing, rule of the court (or a decree) is to be sent, together with the criminal case for the execution to the court that passed the sentence. The court examination of a criminal case after the rejection of judicial decisions, in the view of new or newly revealed circumstances, is executed generally. This involves examination of all the circumstances of the criminal case, without exception, not only new or newly revealed. Decisions made by the court on the basis of a new trial may be appealed by the parties as an appeal and cassation. ${ }^{19}$

Thus, a human rights institute potential of the renewal of production on criminal case in the view of new or newly revealed circumstances can be considered quite high. It is predetermined by the nature of judicial errors. In fact, this institute has been created to correct these errors. Contrary to a widespread view in the literature, we believe that there is nothing exceptional and extraordinary. After all, it is used not instead of, or after other possibilities to review the judicial act has been exhausted, but quite independently. They rely on the revelation of the new circumstances, which have occurred after the court examination or already existed but have been unknown to the court. So the court should examine only those circumstances which don let consider the decisions made to be legal, well-grounded and just.

However, this does not mean that the Criminal Procedure Code of the Russian Federation and its alternations and additions made this trial perfect. There are a lot of drawbacks of different kinds. The past decade has shown that e.g. differentiation of the grounds for renewal of production on criminal case in the view or newly revealed circumstances is not effective because it does not embrace the whole spectrum of the possible judicial errors and as a consequence limits proceeding opportunities to find these errors, correct them and to restore human rights, violated by the illegal decisions. Moreover, pleas

'See: Resolution of the Constitutional Court of RF, dated 16 May 2007. № 6- P. 
of the Constitutional Court of the Russian Federation and the European Court of Human Rights are neither "new" nor " newly revealed" and far from being "circumstances" by their nature. But even despite the quality of Russian courts is far from perfect, it does not seem rational to create a new additional mechanism for revision of pleas. Further increase of the human rights potential of the institution is going to lie in the consistent and more effective improvement of procedures aimed at the elimination of the judicial errors revealed by the courts on the list. We also see the future of the human rights potential of the institution in the lodgment of the interested persons with a right to appeal in the responding court with a petition concerning review of the sentence or other decision if all the grounds for it are present.

\section{Acknowledgments}

None.

\section{Conflicts of interest}

The author declares that there is no conflict of interest.

\section{Funding}

None.

\section{References}

1. Kolokolov NA. Appeal, cassation, supervision: novels of the CCP RF, CCP RF. The first experience of critical thinking. Publishing house «Lawyer». 2011. p. 188.

2. Ashirbekova MT. Manifestations of publicity in the proceeding to resume the criminal case due to new or newly discovered circumstances. The Russian Judge. 2008;5:19-21.

3. Borodinova TG. Reasons and grounds for the resumption of proceedings in the criminal case due to new and newly discovered circumstances. Russian Justice. 2012;12:91-94.

4. Valeev AT, Lytinskiy AM. Appeal and revision of court decisions in criminal cases. Vologda. 2014. p. 174

5. Vedishev NP. Renewal of criminal proceedings in view of new or newly discovered circumstances in the criminal justice system: Russian experience and international practice: The dissertation author's abstract on competition of a scientific degree of the candidate of legal sciences. Specialty 12.00.09-criminal trial, criminology; operatively-search activity. Saratov. 2012. p. 26.

6. Vedishev NP. Resumption of criminal proceedings in view of new or newly discovered circumstances. M: Yurlitinform. 2003. p. 256.
7. Davidov VA. The resumption of criminal proceedings in view of new or newly discovered circumstances: the theory and practice of correcting judicial errors: A monograph. M: Yurayt. 2011. p. 313.

8. Davidov VA. On the turn for the worse in the revision of the criminal case after the cancellation of the sentence, determination, decision in view of new or newly discovered circumstances. Criminal justice: theory and practice. M: Yurayt. 2011. p. 937-942.

9. Dikarev IS. Return of the criminal case to the prosecutor due to the discovery of new circumstances. Legality. 2014;1:46-48.

10. Dikarev IS. The instantaneous review of the court decisions on criminal cases that have come into force: history and modernity. Actual problems of Russian law. 2014;11:2470-2474.

11. Dikarev IS. Supervisory-cassation form of review of court decisions in the criminal procedure: Monography. Volgograd: Publishing house of VolSU. 2016. p. 400.

12. Kalnickiy VV. The stage of cassation (supervisory) proceedings in criminal proceedings: Textbook, Allowance. Omsk: Omsk Academy of the Ministry of Internal Affairs of Russia. 2016;72.

13. Kamchatov KV, Chashhina LV, Velikaja EV. Resumption of proceedings in a criminal case due to new or newly discovered circumstances. Monography. Academy of the Prosecutor General's Office of the Russian Federation. 2015;140.

14. Morshakova TG. Russian Justice in the Context of Judicial Reform. MR: Valent. 2004;264.

15. Oksyk TL. Actual problems of legal regulation of the institute for resuming criminal proceedings in view of new or newly discovered circumstances. Criminal Procedure in modern conditions: the problems of theory and practice. Moscow: Volters Kluver. 2010;316-324.

16. Morshakova TG. Revision of judicial acts in civil, arbitration and criminal proceedings (analytical review of regulatory documents). M: HSE. 2011;266.

17. Potapov MD. The basic principles of verifying judicial decisions in the control and verification stages and the criminal justice proceedings in Russia. M: Yurlitinform. 2012;376.

18. Smirnaya LV. The grounds for the resumption of proceedings in the criminal case due to new or newly discovered circumstances in Russia and CIS countries. International Criminal Law and International Justice. 2017;2:19-22.

19. Ja M Chirjaskina. Actual problems of resuming criminal proceedings due to new or newly discovered circumstances. Lex Russia. 2009;5:1261-1264. 